\title{
Phosphorus dynamics during the transition from nitrogen to phosphate limitation in the central Baltic Sea
}

\author{
Monika Nausch*, Günther Nausch, Norbert Wasmund \\ Baltic Sea Reseach Institute Warnemünde, Seestrasse 15, 18119 Rostock-Warnemünde, Germany
}

\begin{abstract}
Phosphate uptake rate, alkaline phosphatase activity (APA), nucleotidase activity (ATPNA), and nutrient pool sizes were investigated in the eastern Gotland Basin from May until September 2001 to describe the phosphorus dynamics during this period, which is characterized by the transition from nitrogen to phosphate limitation and the development of nitrogen-fixing cyanobacteria. Phosphate concentrations declined from $0.1 \mu \mathrm{M}$ in May to $0.01 \mu \mathrm{M}$ in June. However, the decrease in phosphate was not reflected in increasing organic phosphorus pools. Its concentrations remained at a relatively constant level of $0.4 \mu \mathrm{M}$. Development of plankton biomass in July was based on the intracellular phosphorus pool. The $\left[{ }^{33} \mathrm{P}^{\mathrm{P} O} \mathrm{O}_{4}\right.$ uptake rate and hydrolytic activities increased from very low levels in May to a maximum in July, decreasing in the following months. The development of these activities was associated with the development of heterocystous cyanobacteria. However, size fractionation showed that the $\left[{ }^{33} \mathrm{P}_{\mathrm{PO}_{4}}\right.$ uptake in the fraction $>10 \mu \mathrm{m}$ accounted for only a small portion of the total $\left[{ }^{33} \mathrm{P}^{2} \mathrm{PO}_{4}\right.$ uptake rate, but for $41 \%$ of APA. Due to elevated total phosphorus concentrations of 1.0 and $0.8 \mu \mathrm{M}$ in the buoyant surface blooms, phosphorus dynamics were different compared to situations when cyanobacteria were dispersed in the euphotic zone. Depending on the parameter used, a different length of the period of phosphate limitation can be estimated. Based on $\left[{ }^{33} \mathrm{P}_{\mathrm{PO}_{4}}\right.$ uptake rates and hydrolytic activities, phosphate limitation was restricted to 2 to $4 \mathrm{wk}$ in July. This period is shorter than that indicated by phosphate deficiency and C:P ratios.
\end{abstract}

KEY WORDS: Phosphorus cycle $\cdot$ Phosphate uptake $\cdot$ Alkaline phosphatase activity $\cdot$ Nucleotidase activity $\cdot$ DOP $\cdot$ POP $\cdot$ Baltic Sea

Resale or republication not permitted without written consent of the publisher

\section{INTRODUCTION}

In the Baltic Sea, the heterocystous diazotrophic cyanobacteria Nodularia spumigena and Aphanizomenon sp. are the dominant species of the microphytoplankton in summer (Kononen et al. 1996, Wasmund 1997). Large blooms at the surface occur frequently (Kahru et al. 1994, HELCOM ${ }^{1}$ ). Therefore, nitrogen fixation by these organisms is an important source of nitrogen input into this ecosystem, calculated to be between 2 and $4 \times 10^{5} \mathrm{t} \mathrm{yr}^{-1}$ (Elmgren \& Larsson 2001, Wasmund et al. 2001). There are numerous publica-

${ }^{1}$ HELCOM news 1/2002 newsletter. Available at www.helcom. fi/publications/newsletter2002.pdf tions about nitrogen fixation (Hübel \& Hübel 1980, Leppänen et al. 1988, Stal et al. 1999, Ohlendieck et al. 2000, Stal \& Walsby 2000, Wasmund et al. 2001) and about nutrient conditions promoting the development of nitrogen-fixing cyanobacteria (Niemi 1979, Smith 1983, Groenlund et al. 1996, Pollinger et al. 1998, Levings \& Schindler 1999, Berman 2001, Kononen 2001). In general, a low N:P ratio of dissolved inorganic nutrients is the major prerequisite, as has been demonstrated both by fertilization (Schindler 1977, Yusoff \& McNabb 1997, Rydin et al. 2002) and elimination experiments (Perakis et al. 1996, Holz \& Hoagland 1999), but other factors, such as the temperature, wind and light conditions, and the mixed layer depth, have to be suitable. There is also evidence that phosphate can regulate the 
mechanism of nitrogen fixation itself (Wallström 1988, Wu et al. 2000, Sanudo-Wilhelmy et al. 2001).

For the Baltic Sea, the nutrient conditions in May after the spring bloom, characterized by exhausted dissolved inorganic nitrogen (DIN) and phosphate concentrations of $0.1 \mu \mathrm{M}$, were assumed to be the triggering factor for the development of heterocystous nitrogenfixing cyanobacteria in summer. Although phosphate is important for the development of diazotrophic cyanobacteria, only a few detailed studies are available about phosphorus dynamics in this ecosystem and the role of cyanobacteria within the phosphorus cycle. Phosphate limitation of cyanobacteria and other plankton in summer is primarily deduced from the absence of measurable phosphate concentrations in water, and from high alkaline phosphatase activity (Paasche \& Erga 1988, Graneli et al. 1990, Kononen et al. 1993). Kononen et al. (1993) and Grönlund et al. (1996) presented results of phosphate uptake rates in cyanobacterial blooms in the Gulf of Finland.

In the present study, phosphate uptake rate and hydrolytic activities, as well as nutrient pool sizes, were investigated with high temporal resolution from May until September 2001 during 5 cruises. These were designed to obtain a better understanding of phosphorus dynamics in the central Baltic Sea in relation to the development and dominance of heterocystous cyanobacteria.

\section{MATERIALS AND METHODS}

Water sampling and hydrographic conditions. Investigations were conducted in the eastern Gotland Basin at Stn $271\left(57^{\circ} 19.20^{\prime} \mathrm{N}, 20^{\circ} 03.00^{\prime} \mathrm{E}\right)$ from May until September 2001. On average, 2 depth profiles $d^{-1}$ were sampled in the euphotic layer for 3 or 4 successive days each month. Additionally, in July, buoyant surface blooms were investigated in the SE Gotland Basin at $56^{\circ} 12.68^{\prime} \mathrm{N}, 17^{\circ} 15.20^{\prime} \mathrm{E}$ and $56^{\circ} 33.28^{\prime} \mathrm{N}, 18^{\circ} 02.30^{\prime} \mathrm{E}$ (Blooms A and B).

Samples were taken using a combined Seabird SBE911 CTD and Hydrobios rosette sampler (Hydrobios Apparatebau) equipped with $12 \times 5 \mathrm{l}$ free-flow bottles at 5 depths $(1,2.5,5,10$, and $15 \mathrm{~m})$. With the exception of phytoplankton determinations, all measurements were carried out separately for each depth.

All depths sampled were situated above the thermocline. Due to wind speeds between 6.6 and $9.5 \mathrm{~m} \mathrm{~s}^{-1}$, this layer was well mixed. Mean monthly values of temperature from May to September, respectively, were $6.2,10.9,17.8,19.1$ and $18.1^{\circ} \mathrm{C}$.

The buoyant surface blooms were sampled manually with a separate 21 water sampler (Limnos Oy). During that time, the wind speed was only $1.3 \mathrm{~m} \mathrm{~s}^{-1}$ and the surface temperature was $21.7^{\circ} \mathrm{C}$, the highest of the investigation period. A secondary thermocline was observed at $2.5 \mathrm{~m}$ depth, where the temperature dropped down to $16.0^{\circ} \mathrm{C}$.

Analytical methods. Phosphate was analysed spectrophotometrically by the standard method described by Rohde \& Nehring (1979) and Grasshoff et al. (1983). The detection limit was $0.01 \mu \mathrm{M}$. Duplicate samples for total and dissolved phosphorus and nitrogen were oxidized simultaneously with persulfate in an alkaline medium (Grasshoff et al. 1983), before and after filtration through pre-combusted Whatman GF/F-filters, followed by phosphate and nitrate determination using an autoanalyser system (Alliance Instruments). Dissolved organic phosphorus (DOP) and nitrogen (DON) were calculated as the difference between total dissolved phosphorus (TDP) or nitrogen (TDN) and the respective inorganic nutrients. Particulate organic phosphorus (POP) was calculated as the difference between the total phosphorus content and the dissolved fraction.

Chl a was measured fluorometrically (excitation $450 \mathrm{~nm}$, emission $670 \mathrm{~nm}$ ) after filtration (Whatman GF/F-filter) and extraction in 90\% acetone (UNESCO 1994). Phytoplankton carbon was calculated from chl a concentrations using the conversion factor of 50 on a $\mu \mathrm{g}$ per $\mu \mathrm{g}$ basis (Jost \& Pollehne 1998).

For estimation of particulate organic carbon (POC) and nitrogen (PON), water was filtered through precombusted Whatman GF/F-filters and the filters were stored at $-20^{\circ} \mathrm{C}$ until analysis in a CHN analyser (EA 1110, Fison Instruments).

Phytoplankton bio-volumes and species composition were determined according to HELCOM guidelines (HELCOM 1988). Samples from 1, 2.5, 5, 7.5, and $10 \mathrm{~m}$ depth were mixed in equal amounts to produce an integrated sample. Samples from $15 \mathrm{~m}$ depth were counted separately. Phytoplankton was preserved with acetic Lugol solution $\left(\mathrm{KI} / \mathrm{I}_{2}\right)$ and counted in an inverted microscope (Leica) (Utermöhl 1958). The cell volume was calculated from the size measurements by using the appropriate stereometric formula. It was converted to wet weight ( $\mathrm{ww}_{\mathrm{i}} \mathrm{mg} \mathrm{m}^{-3}$ ), assuming that the density of the plasma is equal to that of water (roughly $1 \mathrm{mg} \mathrm{mm}^{-3}$ ).

Bacteria were counted using an epifluorescence microscope (Zeiss-Axioskop) combined with an image analysis system (Photometrix) and the computer software programme 'IP Lab Spectrum' (Signal Analytic) after staining with 4,6-diamino-2-phenylindol (DAPI). Bacterial carbon was calculated using the conversion factor of $20 \mathrm{fg} \mathrm{cell}^{-1}$ (Lee \& Fuhrman 1987).

Samples for primary production were incubated on deck for $2 \mathrm{~h}$ in $275 \mathrm{ml}$ polycarbonate bottles with $148 \mathrm{kBq} \mathrm{NaH}{ }^{14} \mathrm{CO}_{3}$ at simulated in situ light conditions. Incubations were stopped by filtration on Whatman GF/F-filters. Filters were fumed with concentrated $\mathrm{HCl}$ for $15 \mathrm{~min}$. Radioactivity was counted in 
a liquid scintillation counter (Tri-Carb 2560 TR/X, Packard) using Ultima Gold (Packard) as a scintillation cocktail.

For phosphate uptake, $\left[{ }^{33} \mathrm{P} \mathrm{PO}_{4}\right.$ (Hartmann Analytics; specific activity: $110 \mathrm{TBq} \mathrm{mmol}^{-1}$ ) was added in concentrations of $277 \mathrm{kBq}$ to $50 \mathrm{ml}$ samples (50 pM final concentration) in polycarbonate bottles. For blanks, $500 \mu \mathrm{l}$ formaldehyde was added before radiotracer addition. The incubations were conducted under low light conditions in the laboratory. In preliminary experiments, $\left[{ }^{33} \mathrm{P} \mathrm{PO}_{4}\right.$ uptake did not differ between in situ light or dark incubation. During the total incubation time of $1 \mathrm{~h}$, subsamples of $5 \mathrm{ml}$ were taken at time intervals; $\left[{ }^{33} \mathrm{P} \mathrm{PO}_{4}\right.$ incorporation was stopped by addition of $100 \mu \mathrm{M}$ carrier-free $\mathrm{PO}_{4}$ (Thingstad et al. 1993). Subsamples were filtered onto $0.2 \mu \mathrm{m}$ polycarbonate filters pre-soaked with $1 \mathrm{mM} \mathrm{KH_{2 }} \mathrm{PO}_{4}$. For size fractionation, samples were filtered additionally onto filters with pore sizes of $0.8,3$ and $10 \mu \mathrm{m}$, respectively. Filters were counted in a liquid scintillation counter (Tri-Carb 2560 TR/X, Packard) using Lumasafe Plus (Packard) as a scintillation cocktail. All analyses were performed in triplicate. The $\left[{ }^{33} \mathrm{P} \mathrm{PO}_{4}\right.$ uptake rate was determined from the straight slope of radioactivity incorporated into particulate matter versus incubation time (Ammerman 1993). Turnover times were calculated by the equation $T=t / \ln (1-r)$; where $T=$ turnover time, $t=$ incubation time, $r=$ consumed fraction of added $\left[{ }^{33} \mathrm{P} \mathrm{PO}_{4}\right.$ (Thingstad et al. 1993).

The gross phosphate uptake rate was derived from the $\left[{ }^{33} \mathrm{P} \mathrm{PO}_{4}\right.$ uptake rate and the ambient phosphate concentrations. With exception of the blooms, ambient phosphate concentrations were averaged on all measurements per month.

For substrate kinetic experiments, carrier-free $\mathrm{PO}_{4}$ in concentrations from $50 \mathrm{pM}$ to $2 \mu \mathrm{M}$ was added in addition to the radiotracer.

Phosphate enrichment experiments were conducted in June, July and September. Five litres of surface water was incubated after addition of $1 \mu \mathrm{M}$ phosphate at in situ temperatures and at surface light conditions. At different times during a total incubation time ranging between 33 and $67 \mathrm{~h}$, phosphate concentrations were measured. At the beginning and end of each experiment, the DOP and POP concentrations were determined.

5'nucleotidase activity (ATP-NA) was determined according to the protocol of Ammerman (1993). Triplicates of $10 \mathrm{ml}$ subsamples were incubated with $37 \mathrm{kBq}$ $\left[\gamma^{-33} \mathrm{P}\right] \mathrm{ATP}$ (Hartmann Analytics; specific activity: $74 \mathrm{TBq} \mathrm{mmol}^{-1}$ ) corresponding to a final concentration of $50 \mathrm{pM}\left[\gamma_{-}{ }^{33} \mathrm{P}\right] \mathrm{ATP}$. Incubation was done in the dark for $1 \mathrm{~h}$ and stopped by addition of $100 \mu \mathrm{M}$ carrier-free ATP. The samples were filtered onto $0.2 \mu \mathrm{m}$ polycarbonate filters. The filters and $1 \mathrm{ml}$ of the filtrate (first filtrate) were counted in a liquid scintillation counter.
The other $9 \mathrm{ml}$ of the first filtrate were mixed with $20 \mathrm{mg}$ activated charcoal and $1 \mathrm{ml} 0.03 \mathrm{~N} \mathrm{H}_{2} \mathrm{SO}_{4}$, filtered through a $0.45 \mu \mathrm{m}$ filter (second filtrate) and $1 \mathrm{ml}$ was counted. For blanks, $100 \mu \mathrm{l}$ formaldehyde was added $15 \mathrm{~min}$ before the addition of radiotracers. ATP hydrolysis was calculated using the equations of Ammerman (1993): ATP hydrolysis $\left(\% \mathrm{~h}^{-1}\right)=$ (counts on filters + counts of second filtrate)/(counts on filters + counts of first filtrate) $\times 1 h_{\text {; }}$ uptake of $\mathrm{P}$ released by ATP hydrolysis $=$ counts on filters $/$ (counts on filters + counts of first filtrate) $\times 1 \mathrm{~h}$.

The alkaline phosphatase activity (APA) assay was performed according to Hoppe (1993) using 4-methylumbelliferyl phosphate (MUF-P) (Sigma M 8883) as the fluorogenic substrate. In substrate kinetic experiments, 7 or 8 concentrations of MUF-P from 0.1 to $300 \mu \mathrm{M}$ (final concentration) were added and incubated in the dark. Hydrolysis time (h) was calculated according to the equation of Ammerman (1993): hydrolysis time $(\mathrm{h})=$ fluorescence of $0.1 \mu \mathrm{M}$ MUF standard/slope of fluorescence time course at $0.1 \mu \mathrm{M}$ MUFP. For size fractionation, samples were filtered through $10,3,0.8$, and $0.2 \mu \mathrm{m}$ filters before the addition of $200 \mu \mathrm{M}$ MUF-P. Fluorescence was measured with a spectrofluorimeter (Hitachi) at $364 \mathrm{~nm}$ excitation and $445 \mathrm{~nm}$ emission at intervals of 60 min over a period of $3.5 \mathrm{~h}$. All measurements were done in triplicate. Fluorescence units were calibrated with 6 standard concentrations between 0.03 and $1 \mu \mathrm{M}$ of 4 -methylumbelli-ferone in $0.2 \mu \mathrm{m}$ filtered seawater.

All rate measurements were conducted at in situ temperatures. The equipment was washed in $1 \mathrm{~N} \mathrm{HCl}$ and rinsed with Milli-Q water. The biomass-related phosphate uptake rate and APA were calculated using the sum of bacterial and phytoplankton carbon. Assuming that ATP hydrolysis is mostly attributed to bacteria, the $\left[\gamma-{ }^{33} \mathrm{P}\right]$ ATP hydrolysis rate was calculated per bacterial carbon.

Due to the well-mixed surface layer, no significant differences between 0 and $15 \mathrm{~m}$ could be observed. Additionally, no differences between day and night sampling were found. Therefore, all measured values on each day (10 or more single samples, each measured in duplicate or triplicate) were averaged. Surface blooms were handled separately.

Statistical analyses were performed with the computer program 'Statistica 6'.

\section{RESULTS}

\section{Phosphorus pools and nutrient ratios}

At the beginning of the investigations, 9 and 13 May 2001, phosphate concentrations of $0.1 \mu \mathrm{M}$ were mea- 


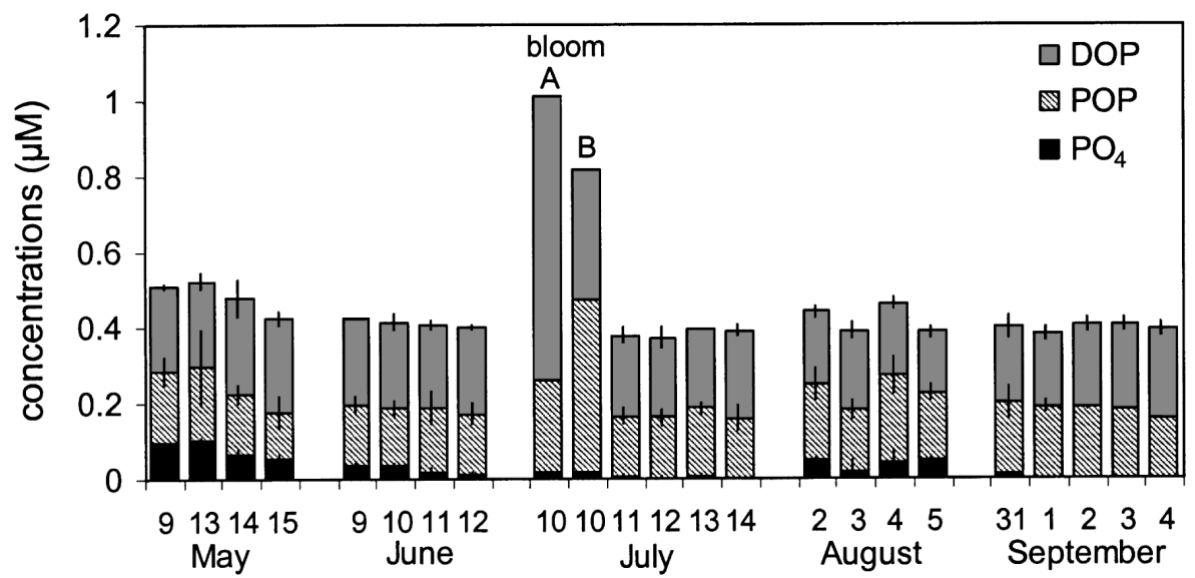

Fig. 1. Concentrations of phosphate, particulate (POP) and dissolved organic phosphorus (DOP) from May until September 2001 sured (Fig. 1). Concentrations declined over the next few weeks and reached the detection limit in the middle of June. In July and September, phosphate was at or below the detection limit. However, during the blooms, concentrations of $0.02 \mu \mathrm{M}$ were measured. Phosphate concentrations were also higher (0.04 \pm $0.02 \mu \mathrm{M}$ ) at the beginning of August, probably because of the breakdown and subsequent mineralization of the heterocystous cyanobacteria.

DOP concentrations (Fig. 1) of 0.20 to $0.23 \mu \mathrm{M}$ were detected during most of the investigation periods. Most variations were not significant and were within the sensitivity range of the method. Much higher DOP values of 0.75 and $0.35 \mu \mathrm{M}$ were measured in the buoyant cyanobacterial blooms. POP concentrations (Fig. 1) varied between 0.15 and $0.20 \mu \mathrm{M}$. Higher concentrations were measured only in July, and then only in samples from surface blooms. Outside the surface blooms, where cyanobacteria were dispersed in water, POP remained at a relatively constant level of $0.18 \mu \mathrm{M}$, despite increasing chl a concentrations compared with May and June. This suggests phosphorus impoverishment of the plankton when cyanobacteria were dispersed. This can be seen also by significant declining POP:biomass ratios from June to July (t-test: $\mathrm{p}<0.0001$ ) (Fig. 2).

$\mathrm{C}: \mathrm{P}$ and $\mathrm{N}: \mathrm{P}$ ratios in particulate organic matter developed in parallel. C:P ratios were above the Redfield ratio from May until August (Table 1). The highest ratios were found during the occurrence of dispersed cyanobacteria in July, when values ranged between 231 and 497 (mean 318). It is remarkable that in the surface blooms in July, C:P ratios were lower. The lowest value was measured in Bloom A, which also had the highest DOP concentration. In September, C:P ratios were close to the Redfield ratio (Table 1).

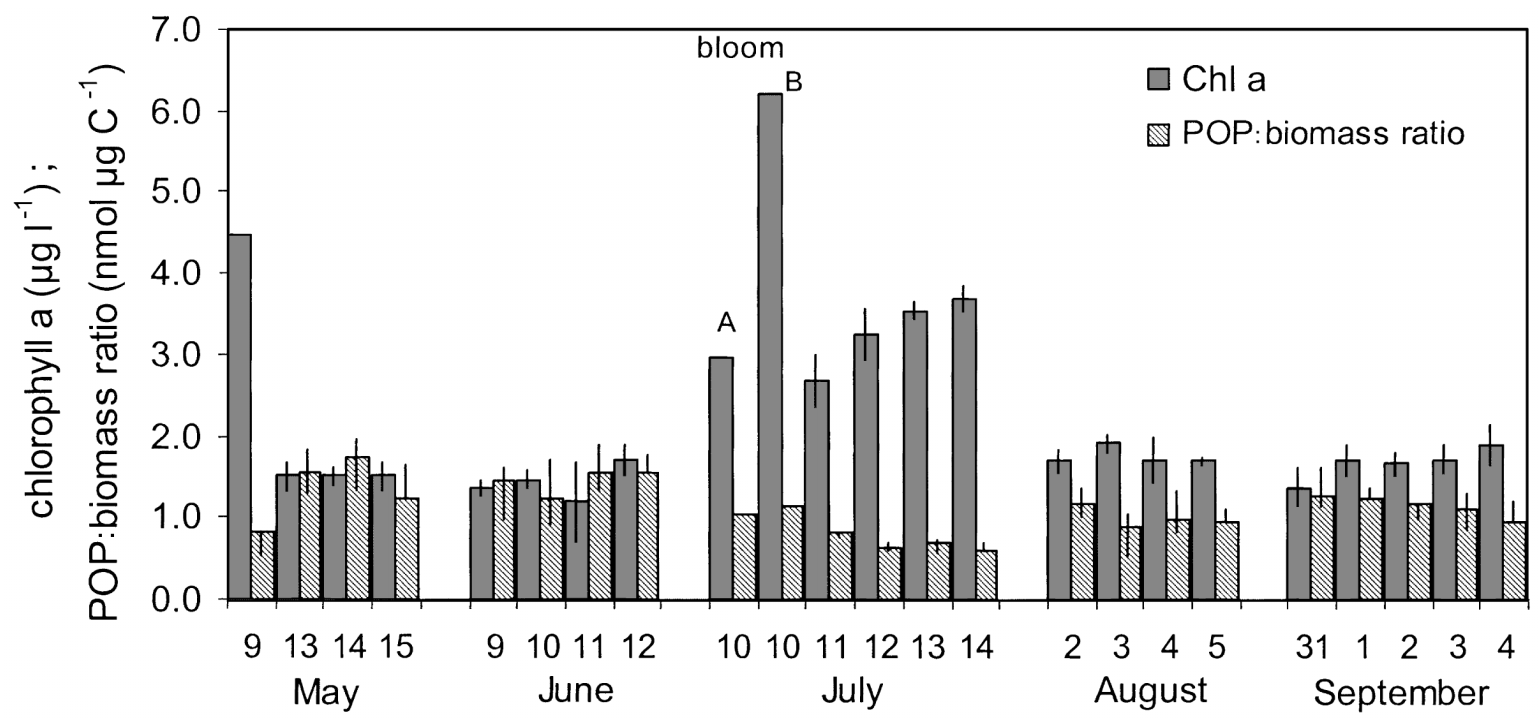

Fig. 2. Chl a concentrations and particulate organic phosphorus (POP):biomass ratios from May until September 2001. Biomass is the sum of phyto- and bacterioplankton carbon. Phytoplankton biomass was calculated from chl $a$ 
Table 1. Mean concentrations of particulate organic nitrogen (PON) and total dissolved organic nitrogen (TDN), as well as ratios between organic nutrient concentrations in particulate and dissolved organic matter. POC, POP: particulate organic carbon and phosphorus; TDP: total dissolved and phosphorus; DON, DOP: dissolved organic nitrogen and phosphorus

\begin{tabular}{|c|c|c|c|c|c|c|c|c|}
\hline & \multicolumn{4}{|c|}{ Particulate matter } & \multicolumn{3}{|c|}{ Dissolved matter } \\
\hline & & $\mathrm{PON}(\mu \mathrm{M})$ & POC:PON & POC:POP & PON:POP & $\mathrm{TDN}(\mu \mathrm{M})$ & TDN:TDP & DON:DOP \\
\hline \multicolumn{2}{|l|}{ May } & $4.2 \pm 0.5$ & $7.2 \pm 0.7$ & $224.9 \pm 98.4$ & $30.8 \pm 12.1$ & $18.0 \pm 1.4$ & $58.9 \pm 3.3$ & $73.9 \pm 6.4$ \\
\hline \multicolumn{2}{|l|}{ June } & $4.1 \pm 0.3$ & $7.2 \pm 0.4$ & $191.5 \pm 28.5$ & $26.8 \pm 3.7$ & $17.0 \pm 0.9$ & $66.0 \pm 4.5$ & $73.9 \pm 5.9$ \\
\hline July & $\begin{array}{l}\text { Bloom A } \\
\text { Bloom B } \\
\text { Dispersed }\end{array}$ & $\begin{array}{c}3.9 \\
14.6 \\
4.0 \pm 1.3\end{array}$ & $\begin{array}{c}11.2 \\
7.3 \\
7.0 \pm 0.6\end{array}$ & $\begin{array}{c}182.6 \\
237.1 \\
318.1 \pm 86.5\end{array}$ & $\begin{array}{l}16.3 \\
32.6 \\
42.9 \pm 15.0\end{array}$ & $\begin{array}{c}19.5 \\
22.2 \\
18.7 \pm 1.2\end{array}$ & $\begin{array}{c}25.4 \\
60.0 \\
81.3 \pm 18.5\end{array}$ & $\begin{array}{c}25.3 \\
61.8 \\
83.8 \pm 8.2\end{array}$ \\
\hline \multicolumn{2}{|c|}{ August } & $3.9 \pm 0.8$ & $7.3 \pm 1.0$ & $177.9 \pm 54.5$ & $24.9 \pm 8.5$ & $19.7 \pm 1.1$ & $82.6 \pm 16.9$ & $97.6 \pm 7.9$ \\
\hline \multicolumn{2}{|c|}{ September } & $2.8 \pm 0.5$ & $7.3 \pm 1.0$ & $117.5 \pm 23.1$ & $16.2 \pm 2.8$ & $19.8 \pm 1.6$ & $102.8 \pm 11.2$ & $103.9 \pm 13.3$ \\
\hline
\end{tabular}

Mean values of TDN ranged between 17.0 and $22.2 \mu \mathrm{M}$ (Table 1) and lay in the annual range of $21 \pm$ $8 \mu \mathrm{M}$ (Matthäus et al. 1999) for this station. DON accounted for between 96.7 and $99.4 \%$ of TDN. With the exception of the surface Bloom A, TDN:TDP and DON:DOP ratios were much higher than the Redfield ratio. In particular in Bloom A (Fig. 1), a high DOP concentration resulted in a decrease of the DON:DOP ratio. Therefore, it can be deduced that in surface blooms, organic phosphorus was released in comparatively higher amounts than nitrogen.

\section{Phytoplankton biomass}

Phytoplankton biomass ( $\mathrm{mg} \mathrm{ww} \mathrm{m}^{-3}$ ) was the same in May and June (Fig. 3). In May, heterocystous

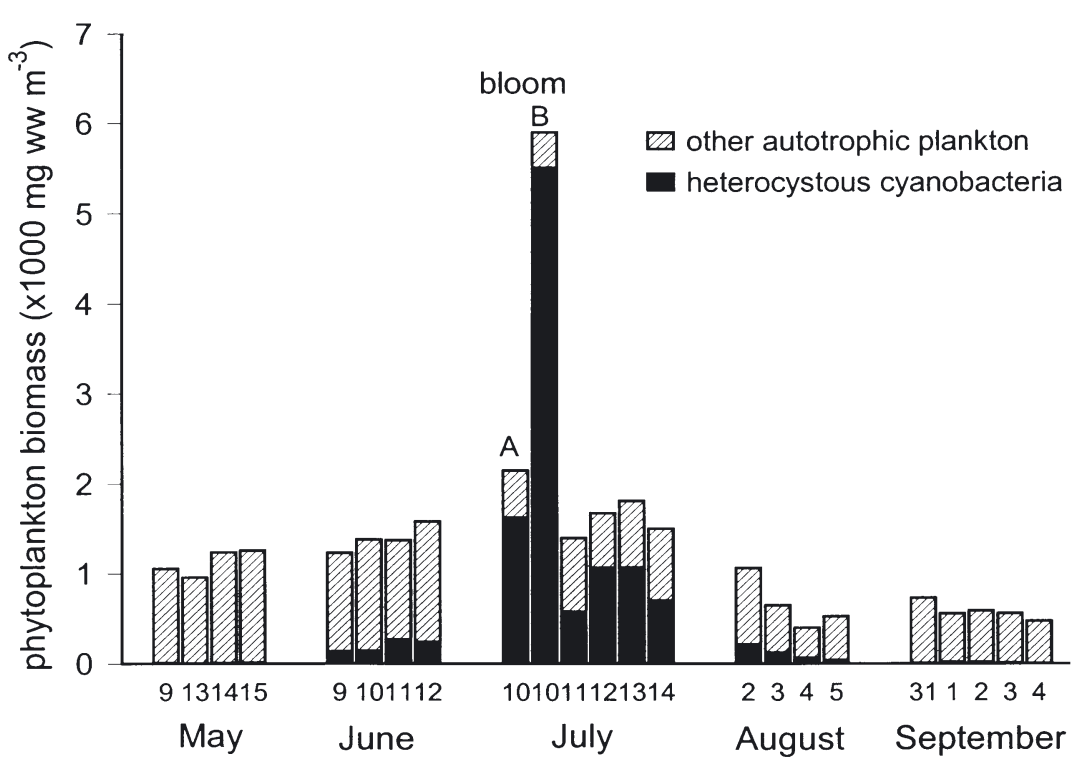

Fig. 3. Development of the biomass of heterocystous cyanobacteria obtained by microscopic counting. ww: wet weight. Numbers under bars are dates in month cyanobacteria accounted for only ca. $1 \%$ of the total phytoplankton biomass. In June, the percentage rose to $10 \%$. The highest biomass of heterocystous cyanobacteria was observed in July. It amounted to 75 and $91 \%$ in the 2 surface blooms, and between 42 and $61 \%$ in dispersed phytoplankton. During the investigations in August, heterocystous cyanobacteria declined from 17 to $7 \%$, and reached a level of $2 \%$ in September.

Heterocystous cyanobacteria consisted of the species Nodularia spumigena and a typical Baltic Aphanizomenon species that is not taxonomically described. In July, N. spumigena dominated the surface blooms, whereas under dispersed conditions Aphanizomenon sp. was present in equal or greater amounts. In June and August, respectively, the biomass of Aphanizomenon sp. was 22 times and 2 to 6 times higher than the biomass of $N$. spumigena. N. spumigena was completely absent in May and September.

\section{Phosphate uptake}

The $\left[{ }^{33} \mathrm{P} \mathrm{PO}_{4}\right.$ uptake rate was lowest $\left(0.01 \% \mathrm{~min}^{-1}\right)$ in May. It increased from May to June by a factor of 8 , and from June to July by a factor of 48 . Afterwards, the $\left[{ }^{33} \mathrm{P} \mathrm{PO}_{4}\right.$ uptake rate decreased and reached a level in September comparable to that in June. The ${ }^{33} \mathrm{P} \mathrm{PO}_{4}$ uptake rate was significantly lower in the surface blooms than for dispersed cyanobacteria. The increase in the $\left[{ }^{33} \mathrm{P} \mathrm{PO}_{4}\right.$ uptake rate from May to July was not only caused by the amount of phytoplankton and bacterial biomass, which was also highest in July. The $\left[{ }^{33} \mathrm{P}\right] \mathrm{PO}_{4}$ uptake rate per biomass showed the same pattern (Fig. 4). Multiple regression analysis was used to estimate 


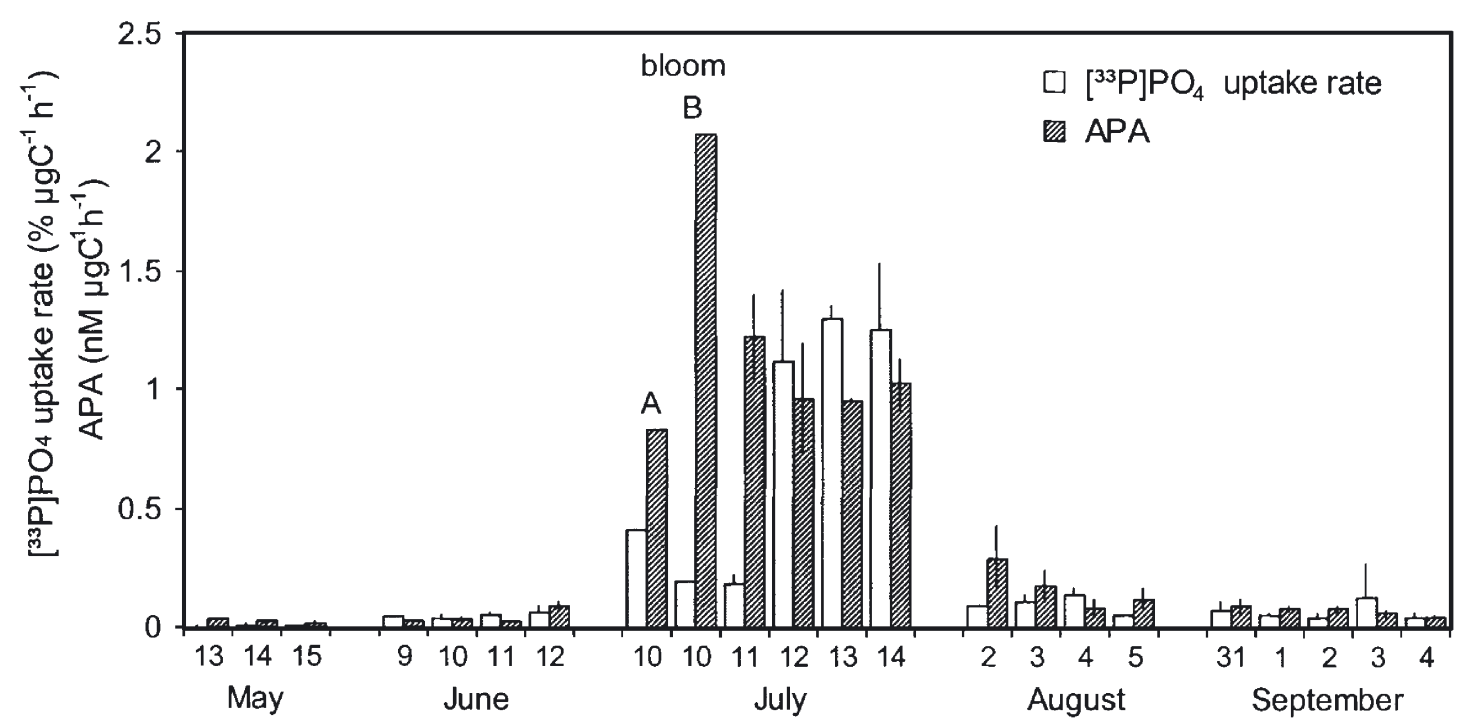

Fig. 4. $\left[{ }^{33} \mathrm{P} \mathrm{PO}_{4}\right.$ uptake rates and alkaline phosphatase activities (APA- $\mathrm{V}_{\max }$ ) normalized to carbon-biomass, pooled for phyto- and bacterioplankton carbon. $\mathrm{V}_{\max }$ : maximum enzyme activity

the influence of different factors on the development of $\left[{ }^{33} \mathrm{P} \mathrm{PO}_{4}\right.$ uptake rate from May until September (Table 2). The combination of all variables resulted in a high significance and can explain $93 \%$ of the variability. Most of the single variables had no significant influence. The closest relationships determined were between the $\left[{ }^{33} \mathrm{P} \mathrm{PO}_{4}\right.$ uptake rate and the ATP-NA hydrolysis rate followed by DOP. However, these relationships were mainly due to the values in the surface blooms. Excluding the blooms from this calculation, the relationships changed and the highest influence was that of the heterocystous cyanobacteria.
Size fractionation (Fig. 5) showed that the fraction $>10 \mu \mathrm{m}$ including heterocystous cyanobacteria always contributed only a small amount to the total $\left[{ }^{33} \mathrm{P} \mathrm{PO}_{4}\right.$ uptake rate: ca. $10 \%$ in June, $2 \%$ in July, $3 \%$ in August, and $5 \%$ in September. In this fraction, the absolute $\left[{ }^{33} \mathrm{P} \mathrm{PO}_{4}\right.$ uptake rate increased by a factor of 4 from June to July. The largest changes in the $\left[{ }^{33} \mathrm{P} \mathrm{PO}_{4}\right.$ uptake rate were observed in the fraction between 0.8 and $3 \mu \mathrm{m}$ and in the fraction between 0.2 and $0.8 \mu \mathrm{m}$, representing small autotrophic picoplankton and bacteria, respectively. In July, both fractions together accounted for $91 \%$ of the $\left[{ }^{33} \mathrm{P}\right] \mathrm{PO}_{4}$ uptake rate.

Table 2. Influence of different parameters on $\left[{ }^{33} \mathrm{P}_{\mathrm{PO}}\right.$ uptake rate, alkaline phosphatase activity (APA) and nucleotidase activity (ATP-NA) detected in multiple regression analysis $(n=20) . \mathrm{R}^{2}$ indicates the degree of influence of the combination of all parameters; $\mathrm{p}$ represents the significance level. POP, DOP: particulate and dissolved organic phosphorus; $\mathrm{V}_{\text {max }}$ : maximum enzyme activity

\begin{tabular}{|c|c|c|c|c|c|c|}
\hline & \multicolumn{2}{|c|}{$\begin{array}{c}{\left[{ }^{33} \mathrm{P} \mathrm{PO}_{4} \text { uptake rate }\right.} \\
\left(\% \mathrm{~min}^{-1}\right)\end{array}$} & \multicolumn{2}{|c|}{$\begin{array}{l}\text { APA- } V_{\max } \\
\left(\mathrm{nM} \mathrm{h}^{-1}\right)\end{array}$} & \multicolumn{2}{|c|}{$\begin{array}{l}\text { ATP-NA } \\
\left(\% \mathrm{~h}^{-1}\right)\end{array}$} \\
\hline & $\begin{array}{l}\text { Blooms } \\
\text { included }\end{array}$ & $\begin{array}{l}\text { Without } \\
\text { blooms }\end{array}$ & $\begin{array}{l}\text { Blooms } \\
\text { included }\end{array}$ & $\begin{array}{l}\text { Without } \\
\text { blooms }\end{array}$ & $\begin{array}{l}\text { Blooms } \\
\text { included }\end{array}$ & $\begin{array}{l}\text { Without } \\
\text { blooms }\end{array}$ \\
\hline $\begin{array}{l}\text { Influence of all included parameters } \\
\text { (all } p<0.002 \text { ) }\end{array}$ & $\mathrm{R}^{2}=0.93$ & $\mathrm{R}^{2}=0.98$ & $\mathrm{R}^{2}=0.98$ & $\mathrm{R}^{2}=0.96$ & $\mathrm{R}^{2}=0.94$ & $\mathrm{R} 2=0.97$ \\
\hline Influence of single parameters: & $\mathrm{p}<$ & $\mathrm{p}<$ & $\mathrm{p}<$ & $\mathrm{p}<$ & $\mathrm{p}<$ & $\mathrm{p}<$ \\
\hline Heterocystous cyanobacteria (mg ww $\mathrm{m}^{-3}$ ) & 0.730 & 0.052 & 0.002 & 0.008 & 0.224 & 0.0004 \\
\hline Other autotrophic plankton ( $\mathrm{mg} \mathrm{ww} \mathrm{m}^{-3}$ ) & 0.059 & 0.876 & 0.86 & 0.881 & 0.532 & 0.044 \\
\hline Heterotrophic bacteria $\left(\mu_{\left.\mathrm{g} \mathrm{C} \mathrm{l}^{-1}\right)}\right.$ & 0.205 & 0.706 & 0.477 & 0.311 & 0.211 & 0.187 \\
\hline Picoplankton (counts $\mathrm{l}^{-1}$ ) & 0.457 & 0.155 & 0.85 & 0.889 & 0.623 & 0.821 \\
\hline Phosphate $(\mu \mathrm{M})$ & 0.93 & 0.860 & 0.456 & 0.665 & 0.637 & 0.904 \\
\hline POP $(\mu \mathrm{M})$ & 0.526 & 0.477 & 0.357 & 0.312 & 0.912 & 0.894 \\
\hline DOP $(\mu \mathrm{M})$ & 0.002 & 0.239 & 0.189 & 0.936 & 0.017 & 0.162 \\
\hline POP:biomass ratio $\left(\mu \mathrm{mol} \mu \mathrm{g} \mathrm{C}^{-1}\right.$ ) & 0.889 & 0.530 & 0.329 & 0.316 & 0.913 & 0.626 \\
\hline $\mathrm{C}: \mathrm{P}$ ratio & 0.923 & 0.328 & 0.282 & 0.913 & 0.102 & 0.969 \\
\hline $\mathrm{APA}-\mathrm{V}_{\max }\left(\mathrm{nM} \mathrm{h}^{-1}\right)$ & 0.074 & 0.132 & - & - & - & - \\
\hline ATP-NA $\left(\% h^{-1}\right)$ & 0.0003 & 0.140 & - & - & - & - \\
\hline
\end{tabular}



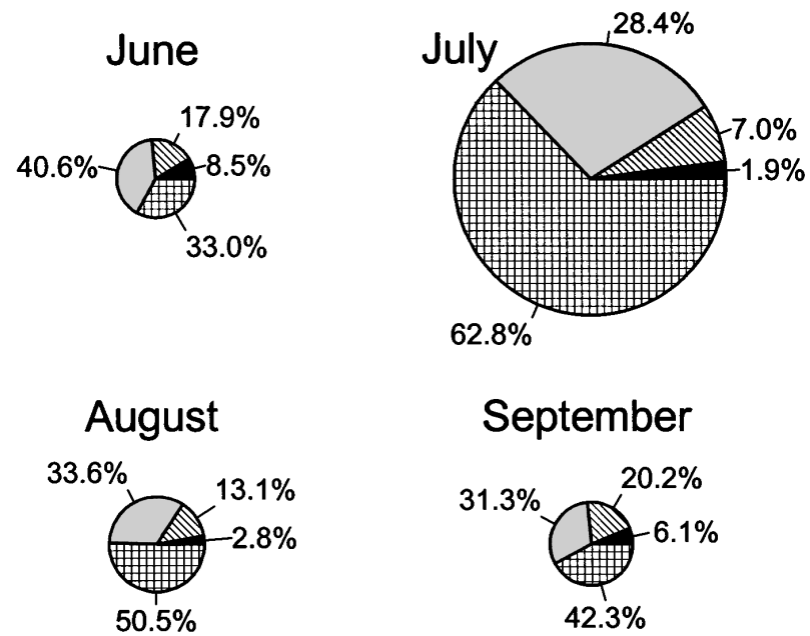

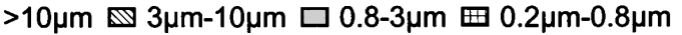

Fig. 5. $\left[{ }^{33} \mathrm{P} \mathrm{PO}_{4}\right.$ uptake of different size fractions. Sizes of the circles indicate the measured uptake rates: $0.11 \% \mathrm{~min}^{-1}$ in June, $2.18 \% \mathrm{~min}^{-1}$ in July, $0.29 \% \mathrm{~min}^{-1}$ in August and $0.16 \% \mathrm{~min}^{-1}$ in September

Table 3. Biomass related phosphate uptake rate calculated from $\left[{ }^{33} \mathrm{P} \mathrm{PO}_{4}\right.$ tracer experiments and ambient phosphate concentrations (gross phosphate uptake rate) ( ${ }^{\mathrm{a}}$ phosphorus released from dissolved organic phosphorus [DOP] is integrated) and from enrichment experiments using the decrease of phosphate and the increase of particulate organic phosphorus at saturation concentrations in substrate kinetic experiments with radiotracers ( $\mathrm{pmol} \mathrm{g} \mathrm{C} \mathrm{C}^{-1} \mathrm{~h}^{-1}$ )

\begin{tabular}{|c|c|c|c|c|}
\hline & \multirow{2}{*}{$\begin{array}{c}\text { Gross phosphate } \\
\text { uptake rate }\end{array}$} & \multicolumn{2}{|c|}{ Enrichment experiments } & \multirow{2}{*}{$\begin{array}{c}\text { Maximum } \\
\text { phosphate uptake }\end{array}$} \\
\hline & & $\mathrm{PO}_{4}$ decrease & POP increase & \\
\hline May & 5.2 & nd & nd & nd \\
\hline June & 14.0 & 19.1 & 12.6 & 35.1 \\
\hline \multicolumn{5}{|l|}{ July } \\
\hline Blooms & $65.8^{\mathrm{a}}$ & 63.0 & 73.9 & nd \\
\hline Dispersed & $35.8^{\mathrm{a}}$ & 35.7 & 33.8 & 434.2 \\
\hline August & 41.7 & nd & nd & 49.1 \\
\hline September & 2.9 & 11.3 & 2.2 & 64.8 \\
\hline
\end{tabular}

Table 4. Comparison of gross phosphate uptake rate in size fraction $>0.8 \mu \mathrm{m}$ and phosphate consumed by phytoplankton calculated from primary production, assuming that $\mathrm{C}$ and $\mathrm{P}$ were taken up at $\mathrm{C}: \mathrm{P}$ ratio of plankton

\begin{tabular}{|lcccc|}
\hline & $\begin{array}{c}\text { Primary } \\
\text { production } \\
\left(\mathrm{mmolC} \mathrm{m}^{-2} \mathrm{~d}^{-1}\right)\end{array}$ & $\begin{array}{c}\text { In situ } \\
\text { C:P ratio }\end{array}$ & $\begin{array}{c}\text { Calculated } \\
\text { P consumption } \\
\left(\mathrm{mmolP} \mathrm{m}^{-2} \mathrm{~d}^{-1}\right)\end{array}$ & $\begin{array}{c}\text { Gross P uptake } \\
\text { rate } \\
\left(\mathrm{mmolP} \mathrm{m}^{-2} \mathrm{~d}^{-1}\right)\end{array}$ \\
\hline May & 68.4 & 225 & 0.3 & 0.13 \\
June & 81.8 & 192 & 0.43 & 0.32 \\
July & 123.9 & 318 & 0.39 & 0.79 \\
August & 165.4 & 178 & 0.93 & 1.32 \\
September & 132.2 & 117 & 1.31 & 0.12 \\
\hline
\end{tabular}

By including the ambient phosphate concentrations in the calculations from $\left[{ }^{33} \mathrm{P}\right] \mathrm{PO}_{4}$ tracer experiments, a phosphate uptake rate can be derived. Gross rates were highest in the surface blooms observed in dispersed cyanobacteria in July and in August. The lowest gross uptake rates were calculated in September (2.9 pmol mg $\mathrm{C}^{-1} \mathrm{~h}^{-1}$ ) (Table 3).

Phosphate enrichment experiments supported the findings from the $\left[{ }^{33} \mathrm{P}_{\mathrm{PO}_{4}}\right.$ tracer experiments, with the highest phosphate uptake in July. Phosphate concentrations decreased during the first $24 \mathrm{~h}$ of incubation by ca. $0.1 \mu \mathrm{M}$ in June and September, but by $0.65 \mu \mathrm{M}$ in the surface blooms, and $0.4 \mu \mathrm{M}$ in dispersed plankton in July. The decrease of phosphate blooms was degraded during an incubation time $33 \mathrm{~h}$ from 0.75 to $0.54 \mu \mathrm{M}$ in Bloom $\mathrm{A}$, and from 0.35 to $0.24 \mu \mathrm{M}$ in Bloom B.

Phosphate uptake rates calculated from phosphate reduction and from the POP increase in enrichment experiments were similar to gross uptake rates obtained from radiotracer experiments and ambient phosphate concentrations (Table 3). However, from substrate kinetic experiments with short incubation times, the maximum phosphate uptake rate at saturation concentrations was 3 times higher in June and 12 times higher in July compared with the uptake rate from tracer and enrichment experiments. In September, there was also a considerable difference between the maximum phosphate uptake rate and the other measurements. In August, differences could be neglected. Phosphate saturation was reached always at $0.5 \mu \mathrm{M}$.

The gross phosphate uptake rates in Table 3 were compared with the phosphate consumption of phytoplankton deduced from primary production, assuming that $\mathrm{C}$ and $\mathrm{P}$ were taken up at the $\mathrm{C}: \mathrm{P}$ ratio determined in particulate organic material (Table 4). In May, June, and September, measured phosphate uptake rates were lower than the calculated consumption. In contrast to that, phosphate uptake rates did exceed consumption in July and August. 
Table 5. Turnover times of phosphate and hydrolysis times for organic phosphorus compounds sensitive to alkaline phosphatase activity (APA) and nucleotidase activity (ATP-NA)

\begin{tabular}{|lccc|}
\hline & $\begin{array}{c}\text { Phosphate } \\
\text { turnover times }(\mathrm{h})\end{array}$ & $\begin{array}{c}\text { APA } \\
(\mathrm{h})\end{array}$ & $\begin{array}{c}\text { ATP-NA } \\
(\mathrm{h})\end{array}$ \\
\hline May & $179.3 \pm 92.5$ & $10042.1 \pm 13938.9$ & $29.8 \pm 10.1$ \\
June & $22.2 \pm 17.1$ & $490.2 \pm 299.1$ & $23.1 \pm 5.3$ \\
July & & & \\
Bloom A & 1.0 & 6.6 & 1.6 \\
Bloom B & 1.3 & 3.5 & 1.4 \\
Dispersed & $0.4 \pm 0.3$ & $6.5 \pm 1.9$ & $2.1 \pm 0.7$ \\
August & $8.7 \pm 6.7$ & $33.9 \pm 11.9$ & $4.9 \pm 1.4$ \\
September & $11.0 \pm 4.3$ & $142.3 \pm 53.9$ & $8.2 \pm 2.8$ \\
\hline
\end{tabular}

\section{Hydrolytic activities}

APA and ATP-NA (Fig. 4, Table 5) developed in parallel to the occurrence of heterocystous cyanobacteria. In July, APA was lower in the surface Bloom A, which was characterized by high DOP concentrations. ATPNA did not differ between the 2 blooms or between the surface-accumulated and dispersed situations. Multiple regression analysis demonstrated that heterocystous cyanobacteria influenced the hydrolytic activities to a higher degree than the phosphate uptake rate. However, when surface blooms were included in the calculation, DOP became the dominant factor influencing the ATP-NA.

Hydrolysis times and phosphate turnover times (Table 5) were used to compare the hydrolytic activities with the phosphate uptake rate. Hydrolysis times obtained by APA were always longer than the turnover times of phosphate. These differences became especially pronounced in May, June and September, indicating the minor importance of APA for phosphate release from organic phosphorus compounds. In contrast, the hydrolysis time obtained by ATP-NA was
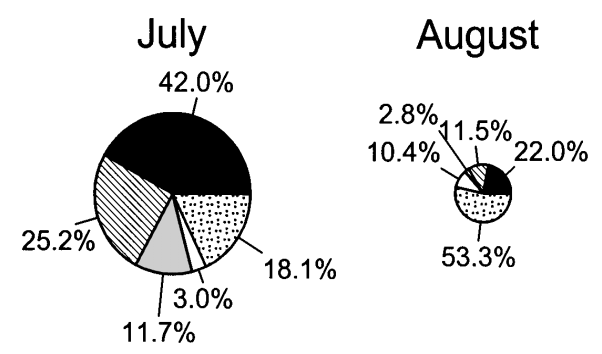

\section{September}

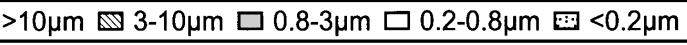

Fig. 6. Alkaline phosphatase activity (APA- $\mathrm{V}_{\max }$ ) in different size fractions in July, August and September 2001. Sizes of the circles indicate the measured activities: $288.93 \mathrm{nmol}^{-1} \mathrm{~h}^{-1}$ in July, $42.28 \mathrm{nmol} \mathrm{l}^{-1} \mathrm{~h}^{-1}$ in August and $16.27 \mathrm{nmol} \mathrm{l}^{-1} \mathrm{~h}^{-1}$ in September shorter or lay in the same range as the phosphate turnover times.

Size fractionation of APA (Fig. 6) showed that $42 \%$ of hydrolytic activity was found in the fraction $>10 \mu \mathrm{m}$ in July under dispersed conditions. Only $3 \%$ of the activity was found in the fraction $<0.8 \mu \mathrm{m}$. The percentage of APA in the fraction $>10 \mu \mathrm{m}$ decreased in August and September, down to 18 and $22 \%$, respectively. In these months, the percentage of soluble APA $(<0.2 \mu \mathrm{m})$ comprised ca. $50 \%$ of the total activity, compared to $18 \%$ in July.

Using the $\left[\gamma^{-33} \mathrm{P}\right] \mathrm{ATP}$ method, the portion of phosphate that was taken up immediately from hydrolysed ATP was estimated (Fig. 7). It ranged between 20 and $40 \%$ in May and June, increased to $>90 \%$ in July, and decreased afterwards to $40 \%$ in September. The lower percentage taken up in the blooms can be again an effect of the dilution of released phosphorus by phosphate or DOP.

\section{DISCUSSION}

Phosphorus dynamics during the transition from nitrogen to phosphate limitation in the surface layer of the central Baltic Sea can be described in detail from measurements with high temporal resolution from May until September 2001.

Decreasing phosphate concentrations from May to June did not result in increases of POP or DOP. Phosphorus must have been exported from the euphotic zone to keep the DOP and POP concentrations in the mixed surface water relatively constant. The following biomass increase from June to July led to a corresponding decrease of POP:biomass ratios. Therefore, plankton growth in this period is based mainly on intracellular phosphorus. In buoyant surface blooms, total phosphorus concentrations were considerably higher compared to situations when cyanobacteria were dispersed in the euphotic layer. These high phosphorus concentrations could be a result of the accumulation of algae and subsequent DOP release. In that case, the POP:biomass ratio should have been lower and the C:P ratio in plankton should have been higher in the surface blooms in comparison to dispersed cyanobacteria. But in our investigations, POP:biomass ratios were significantly higher and C:P ratios significantly lower in the surface blooms compared to dispersed cyanobacteria. Kononen et al. (1996) and Kononen (2001) showed that local upwelling in salinity frontal regions and short-duration wind-induced mixing events with phosphate input promote cyanobacterial growth. In 1993, such a local event in the Gulf of Finland led to an increase in phosphate concentrations 


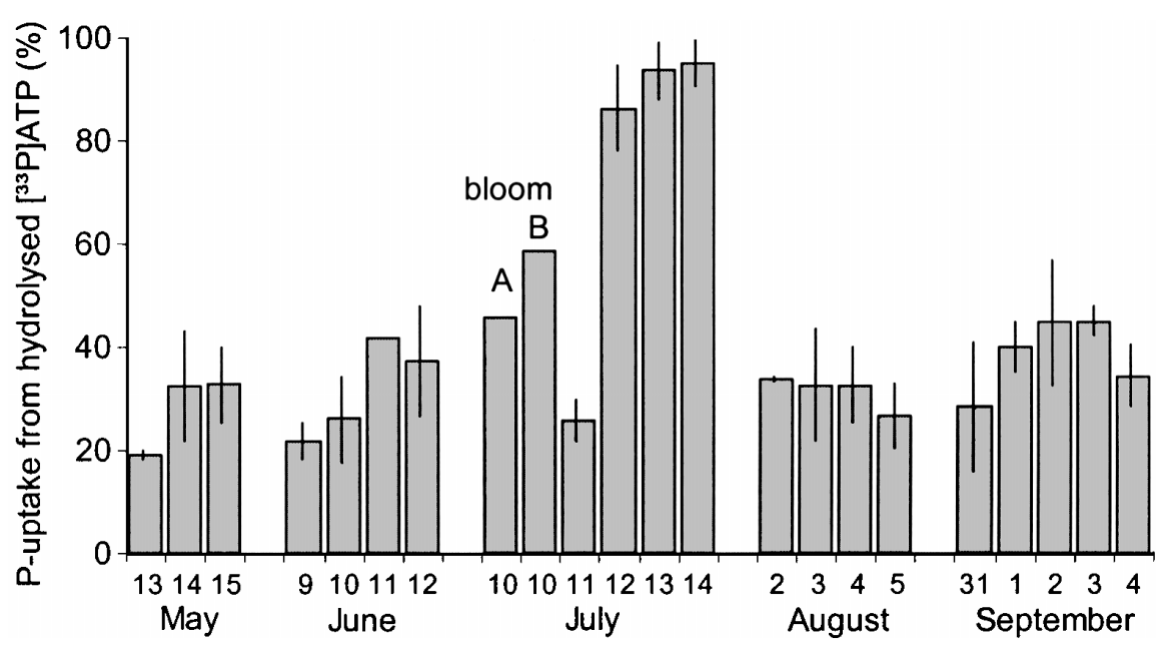

Fig. 7. Percentage of phosphorus taken up from hydrolyzed $\left[\gamma_{-}{ }^{33} \mathrm{P}\right] \mathrm{ATP}$ vations of the size distribution of organisms responsible for the $\left[{ }^{33} \mathrm{P} \mathrm{PO}_{4}\right.$ uptake were made by Grönlund et al. (1996) in a cyanobacterial bloom in the Baltic Sea, but it seems to be a widely distributed phenomenon in aquatic ecosystems, especially when phosphate is deficient (Lean \& White 1983, Currie \& Kalf 1984, Berman 1985, Currie 1986, Thingstad et al. 1993, Björkman \& Karl 1994, Cotner et al. 2000, Labry et al. 2002). This behaviour is explained by the greater affinity of small organisms for phosphate at low phosphate concentrations. The advantage of phosphate uptake by small organisms over larger ones at low phosphate concentrations of $0.015 \mu \mathrm{M}$ in the upper mixed layer, sufficient for large-sized plankton growth (Thingstad et al. 1993, Kononen et al. 1996). Such events could also explain the total phosphorus concentrations and POP:biomass ratios as well as C:P ratios in the surface blooms, as observed in our study. Groenlund et al. (1996) reported that the growth of Aphanizomenon flos-aquae in the Gulf of Finland was benefited by nutrient pulses with an inorganic N:P ratio of 15 in frontal regions. According to Kononen et al. (1996), Nodularia blooms are initiated when a surface layer with higher temperatures was isolated by calm situations after such nutrient pulses. We also observed a secondary thermocline and dominance of Nodularia spumigena in the buoyant surface blooms.

Gross phosphate uptake rates are a more appropriate way to describe the phosphate dynamics than the $\left[{ }^{33} \mathrm{P} \mathrm{PO}_{4}\right.$ uptake rates alone. Elevated phosphate concentrations and phosphate release from DOP can be responsible for the reduced $\left[{ }^{33} \mathrm{P} \mathrm{PO}_{4}\right.$ uptake rates in buoyant surface blooms, because these dilute the added radiotracers. The gross uptake rates showed that phosphate turnover was highest in the surface blooms. Furthermore, the gross phosphate uptake rate demonstrated that phosphate turnover remained at a high level in August, when heterocystous cyanobacteria occurred only in low abundances. However, the results from these 2 mo may be based on different mechanisms. In July, when cyanobacteria were dispersed, the gross phosphate uptake rate is caused by intensive activity of organisms, whereas in August and in the surface blooms, the gross phosphate uptake rate could be attributed to elevated phosphate concentrations.

In size-fractionation experiments, heterocystous cyanobacteria contributed only a small proportion to the $\left[{ }^{33} \mathrm{P} \mathrm{PO}_{4}\right.$ uptake. $\left[{ }^{33} \mathrm{P}\right] \mathrm{PO}_{4}$ uptake was predominantly caused by the size fraction $<3 \mu \mathrm{m}$. Similar obser- can be overcome at higher phosphate concentrations (Lean \& Pick 1981, Robarts et al. 1998). phosphate uptake by phytoplankton found in our investigations have also been observed in other ecosystems. Currie (1986) found in Lake Memphremagog (North America) that orthophosphate uptake supplied only a very small portion of the P required for algal growth, especially in the fraction $>3 \mu \mathrm{m}$. He concluded that sources other than orthophosphate had to be used. In contrast, Canellas et al. (2000) observed for most of the Atlantic Ocean that phosphate availability exceeded the phosphate demand, and concluded that other essential nutrients were lacking. Healy (1982) described elevated phosphate uptake exceeding the maximum growth rate in batch cultures of cyanobacteria. The difference between the phosphate uptake rate and the phosphate consumption in May and September could lead to phosphorus impoverishment of plankton. At present, we cannot explain the discrepancy in July when the phosphate uptake was higher than the phosphate demand.

In our investigations, APA seems to be directly affected by the abundance of heterocystous cyanobacteria. This is valid also for the close coupling of phosphate regeneration and phosphate uptake. Ambient phosphate concentrations are thought to be the most important regulating factor of APA (Jansson et al. 1988, Paasche \& Erga 1988, Ammerman 1991, Bangin et al. 2000). According to multiple regression analysis, it seems to be of minor importance here. At phosphate concentrations of 0.02 to $0.06 \mu \mathrm{M}$, as found in August, APA is normally high (Connors et al. 1996, Nausch 1998) but was low in our investigations. Although phosphate concentrations were at or below the detection limit in July and September, APA levels were quite different for both months. Different cellular phosphorus contents in July and September, deduced from
Discrepancies between phosphate demand and 
C:P and POP:biomass ratios, could be the reason. As shown by Huber \& Hamel (1985), the internal phosphorus pool also influences the APA.

The absence of ambient levels of phosphate, the C:P ratio in particulate organic material, APA, and turnover times of phosphate were used for characterization of the phosphate limitation of plankton in various ecosystems (Graneli et al. 1990, Fisher et al. 1992, Thingstad et al. 1993, Cotner et al. 1997, Evans \& Prepas 1997, Robarts et al. 1998). Our investigations showed that the estimated time of phosphate limitation varied with the parameter used. Phosphate was below the detection limit from the middle of June until September, with an interruption in August. The C:P ratios in particulate organic matter were above the Redfield ratio from May until August. However, the C:P values were influenced by the breakdown of plankton blooms, as in May. The POP:biomass ratio was more consistent with the phosphate turnover times and APA. On the basis of POP:biomass ratios and these activities, and including observations of previous years, phosphate limitation in the central Baltic Sea is restricted to a period of 2 to $4 \mathrm{wk}$, and occurs predominately in the first half of July. This time is short compared to the time calculated by phosphate concentrations and C:P ratios. According to the latter parameters, phosphate limitation would last more than 2 mo.

\section{CONCLUSIONS}

The phosphorus dynamics in the euphotic layer of the central Baltic Sea during the transition from nitrogen to phosphate limitation that occurs from May until September can be summarized as follows:

- Phosphate depletion from May until June was not reflected in increasing dissolved and particulate phosphorus. The total organic phosphorus pool remained relatively constant from the middle of June until September. The development of plankton biomass from May until July was based predominantly on the particulate organic phosphorus pool.

- Phosphate limitation was observed in the first half of July, when heterocystous cyanobacteria were most abundant. Phosphate limitation, calculated on the basis of $\left[{ }^{33} \mathrm{P} \mathrm{PO}_{4}\right.$ uptake rates and hydrolytic activities, was restricted to 2 to $4 \mathrm{wk}$. This period is shorter than indicated by phosphate deficiency and C:P ratios.

- Phosphorus dynamics in buoyant surface blooms of heterocystous cyanobacteria and dispersed cyanobacteria differed. Surface blooms are characterized by elevated total phosphorus, especially DOP, which led to high gross phosphate uptake rate and lower APA. According to turnover times of phosphate and POP:biomass ratios, dispersed cyanobacteria were more phosphate-limited than surface blooms.

\section{LITERATURE CITED}

Ammerman JW (1991) Role of ecto-phosphorylases in phosphorus regeneration in estuarine and coastal ecosystems. In: Chrost RJ (ed) Microbial enzymes in aquatic environments. Springer-Verlag, New York, p 165-186

Ammerman JW (1993) Microbial cycling of inorganic and organic phosphorus in the water column. In: Kemp PF, Sherr BF, Sherr EB, Cole JJ (eds) Handbook of methods in aquatic microbial ecology. Lewis Publishers, Boca Raton, FL, p 649-660

Bangin H, Shiyu H, Yang W, Huasheng H (2000) Effect of dissolved phosphorus on alkaline phosphatase activity in marine microalgae. Acta Oceanol Sinica 19:29-35

Berman T (1985) Uptake of $\left[{ }^{33} \mathrm{P}\right]$ orthophosphate by algae and bactzeria in Lake Kinneret. J Plankton Res 7:71-84

Berman T (2001) The role of DON and the effect of N:P ratio on occurrence of cyanobacterial blooms: implications from the outgrowth of Aphanizomenon in Lake Kinneret. Limnol Oceanogr 46:443-447

Björkman K, Karl DM (1994) Bioavailability of inorganic and organic phosphorus compounds to natural assemblages of microorganisms in Hawaiian coastal waters. Mar Ecol Prog Ser 111:265-273

Canellas M, Augustí S, Duarte CM (2000) Latitudinal variability in phosphate uptake in the Central Atlantic. Mar Ecol Prog Ser 194:283-294

Connors SD, Auer MT, Effler SW (1996) Phosphorus pools, alkaline phosphatase activity, and phosphorus limitation in hypereutrophic Onondaga Lake. Lake Reserv Manage $12: 47-57$

Cotner JB, Ammerman JW, Peele ER, Bentzen E (1997) Phosphorus-limited bacterioplankton growth in the Sargasso Sea. Aquat Microb Ecol 13:141-149

Cotner JB, Sada RH, Bootsma H, Johengren T, Cavaletto F, Gardner WS (2000) Nutrient limitation of heterotrophic bacteria in Florida Bay. Estuaries 23:611-620

Currie DJ (1986) Does orthophosphate uptake supply sufficient phosphorus to phytoplankton to sustain their growth. Can J Fish Aquat Sci 43:1482-1487

Currie DJ, Kalf J (1984) The relative importance of bacterioplankton and phytoplankton in phosphorus uptake in freshwater. Limnol Oceanogr 29:311-321

Elmgren R, Larsson U (2001) Nitrogen and the Baltic Sea: managing nitrogen in relation to phosphorus. The Scientific World 1(S2):371-377

Evans JC, Prepas EE (1997) Relative importance of iron and molybdenum in restricting phytoplankton biomass in high phosphorus saline lakes. Limnol Oceanogr 42:461-472

Fisher TR, Peele ER, Ammerman JW, Harding LW (1992) Nutrient limitation of phytoplankton in Chesapeake Bay. Mar Ecol Prog Ser 82:51-63

Graneli E, Wallström K, Larsson U, Graneli W, Elmgren R (1990) Nutrient limitation of primary production in the Baltic Sea area. Ambio 19:142-151

Grasshoff K, Ehrhardt M, Kremling K (eds) (1983) Methods of seawater analysis, 2nd edn. Verlag Chemie, Weinheim

Groenlund L, Kononen K, Lahdes E, Mäkelä K (1996) Community development and modes of phosphorus utilization in a late summer ecosystem in the central Gulf of Finland, the Baltic Sea. Hydrobiologia 331:97-108

Healey FP (1982) Phosphate. In: Carr NG, Whitton BA (eds) The biology of cyanobacteria. Blackwell Scientific Publications, Oxford, p 105-125

HELCOM (Helsinki Commission) (1988) Guidelines for the Baltic Sea Monitoring Programme for the third stage. Baltic Sea Environment Protection Commission, 27D 
Holz JC, Hoagland KD (1999) Effects of phosphorus on water quality: comparison of alum-treated and untreated portions of a hypereutrophic lake. Lake Reserv Manage 15: $70-82$

Hoppe HG (1993) Use of fluorogenic model substrates for extracellular enzyme activity (EEA) measurement of bacteria. In: Kemp PF, Sherr BF, Sherr EB, Cole JJ (eds) Handbook of methods in aquatic microbial ecology. Lewis Publishers, Boca Raton, FL, p 423-431

Hübel H, Hübel M (1980) Nitrogen fixation during blooms of Nodularia in coastal waters and brackwaters of the Arkona Sea (Baltic Sea) in 1974. Int Rev Gesamten Hydrobiol 65:793-808

Huber AL, Hamel KS (1985) Phosphatase activities in relation to phosphorus nutrition in Nodularia spumigena (cyanobacteriaceae) 1. Field studies. Hydrobiologia 123:145-152

Jansson M, Olsson H, Pettersson K (1988) Phosphatases: origin, characteristics and functioning in lakes. Hydrobiologia 170:157-175

Jost G, Pollehne F (1998) Coupling of autotrophic and heterotrophic processes in a Baltic estuarine mixing gradient (Pomeranian Bight). Hydrobiologia 363:107-115

Kahru M, Horstmann U, Rud O (1994) Satellite detection of increased cyanobacteria blooms in the Baltic Sea: natural fluctuations or ecosystem changes? Ambio 23:469-472

Kononen K (2001) Eutrophication: harmful algal blooms and species diversity in phytoplankton communities: examples from the Baltic Sea. Ambio 30:184-189

Kononen K, Lahdes EO, Grönlund L (1993) Physiological and community responses of summer plankton to nutrient manipulation in the Gulf of Finland (Baltic Sea) with special references to phosphorus. Sarsia 78:243-253

Kononen K, Kuparinen J, Mäkelä K, Laanemets J, Pavelson J, Nömmann S (1996) Initiation of cyanobacterial blooms in a frontal region at the entrance to the Gulf of Finland, Baltic Sea. Limnol Oceanogr 41:98-112

Labry C, Herbland A, Delmas D (2002) The role of phosphorus on planktonic production of the Gironde plume waters in the Bay of Biscay. J Plankton Res 24:97-117

Lean DR, Pick FR (1981) Photosynthetic response of lake plankton to nutrient enrichment: a test for nutrient limitation. Limnol Oceanogr 26:1001-1019

Lean DRS, White W (1983) Chemical and radiotracer measurements of phosphorus uptake by lake plankton. Can J Fish Aquat Sci 40:147-155

Lee S, Fuhrman JA (1987) Relationship between biovolume and biomass of natural derived marine bacterioplankton. Appl Environ Microbiol 53:1298-1303

Leppänen JM, Niemi Ä, Rinne I (1988) Nitrogen fixation of cyanobacteria (blue green algae) and the nitrogen cycle of the Baltic Sea. Symbios 6:181-194

Levings CD, Schindler JE (1999) Influence of nitrogen to phosphorus supply ratios and physicochemical conditions on cyanobacteria and phytoplankton species composition in the experimental lake area, Canada. Can J Fish Aquat Sci 56:451-466

Matthäus W, Nausch G, Lass HU, Nagel K, Siegel H (1999) Hydrographische Zustandseinschätzung der Ostsee 1998. Meereswiss Ber 35:1-69

Nausch M (1998) Alkaline phosphatase activities and the relationship to inorganic phosphate in the Pomeranian Bight (southern Baltic Sea). Aquat Microb Ecol 16:87-94

Niemi Å (1979) Blue green algal blooms and N:P ratios in the Baltic Sea. Acta Bot Fenn 110:59-61

Editorial responsibility: Otto Kinne (Editor),

Oldendorf/Luhe, Germany
Ohlendieck U, Stuhr A, Siegmund H (2000) Nitrogen fixation by diazotrophic cyanobacteria in the Baltic Sea and transfer of the newly fixed nitrogen to picoplankton organisms. J Mar Syst 25:213-219

Paasche E, Erga SR (1988) Phosphorus and nitrogen limitation of phytoplankton in the inner Oslofjord (Norway). Sarsia 73:229-243

Perakis SS, Welch EB, Jacoby JM (1996) Sediment-to-water blue-green algal recruitment in response to alum and environmental factors. Hydrobiologia 318:165-177

Pollinger U, Hadas O, Yacobi YZ, Zohary T, Berman T (1998) Aphanizomenon ovalisporum (Forti) in Lake Kinneret, Israel. J Plankton Res 20:1339-1339

Robarts RD, Waiser MJ, Hadas O, Zohary T (1998) Relaxation of phosphorus limitation due to typhoon-induced mixing in two morphological distinct basins of Lake Biwa, Japan. Limnol Oceanogr 43:1023-1036

Rohde KH, Nehring D (1979) Ausgewählte Methoden zur Bestimmung von Inhaltsstoffen im Meer- und Brackwasser. Geod Geophys Veröff Berlin Ser IV 27:1-68

Rydin E, Hyenstrand P, Gunnerhed M, Blomqvist P (2002) Nutrient limitation of cyanobacterial blooms: an enclosure experiment from the coastal zone of the NW Baltic proper. Mar Ecol Prog Ser 239:31-36

Sanudo-Wilhelmy SA, Kustka, AB, Gobler JC, Hutchins DA and 6 others (2001) Phosphorus limitation of nitrogen fixation by Trichodesmium in the central Atlantic Ocean. Nature 411:66-69

Schindler DW (1977) Evolution of phosphorus limitation in lakes. Science 195:260-262

Smith VH (1983) Low nitrogen to phosphorus ratios favour dominance by blue-green algae in lake phytoplankton. Science 221:669-671

Stal LJ, Walsby AE (2000) Photosynthesis and nitrogen fixation in a cyanobacterial bloom in the Baltic Sea. Eur J Phycol 35:97-108

Stal LJ, Staal M, Villbrandt M (1999) Nutrient control of cyanobacterial blooms in the Baltic Sea. Aquat Microb Ecol 18:165-173

Thingstad TF, Skjoldal EF, Bohne RA (1993) Phosphorus cycling and algal-bacterial competition in Sandsfjord, western Norway. Mar Ecol Prog Ser 99:239-259

UNESCO (1994) Protocols for the Joint Global Ocean Flux Study (JGOFS) core measurements. IOC/SCOR manual and guides 29. UNESCO, Paris, p 128-134

Utermöhl H (1958) Zur Vervollkommnung der quantitativen Phytoplankton-Methodik. Mitt Int Ver Theor Angew Limnol 9:1-38

Wallström K (1988) The occurrence of Aphanizomenon flosaquae (cyanophyceae) in a nutrient gradient in the Baltic. Kiel Meeresforsch SH 6:210-220

Wasmund N (1997) Occurence of cyanobacterial blooms in the Baltic Sea in relation to environmental conditions. Int Rev Gesamten Hydrobiol 82:169-184

Wasmund N, Voss M, Lochte K (2001) Evidence of nitrogen fixation by non-heterocystous cyanobacteria in the Baltic Sea and recalculation of a budget of nitrogen fixation. Mar Ecol Prog Ser 214:1-14

Wu J, Sunda W, Boyle EA, Karl DM (2000) Phosphate depletion in the western North Atlantic Ocean. Science 289: 759-762

Yusoff FM, McNabb CD (1997) The effects of phosphorus and nitrogen on phytoplankton dominance in tropical fish ponds. Aquacult Res 28:591-597

Submitted: December 12, 2002; Accepted: October 7, 2003

Proofs received from author(s): January 19, 2004 